\title{
Jiří Mahen očima Milana Suchomela
}

\author{
Jiří Rambousek
}

\begin{abstract}
Jiří Mahen as Seen by Milan Suchomel

The paper deals with Jiné oči Jiřího Mahena, a book by Milan Suchomel published together in one volume with a re-edition of Měsíc (1st ed. 1920, 2nd ed. 1968, 3rd 1997) written by Mahen. In Měsic, Milan Suchomel reveals the contemplation of the author on metaphysical problems of a person and the cosmos, and claims that Mahen has been a predecessor of existentialism in Czech literature. He deals with other issues related to Mahen (his opinion on the development and the current state of Czech literature, his connection to literary works by Karel Hynek Mácha etc.). Therefore, the book can be considered a peculiar monography of works by Jiří Mahen.
\end{abstract}

\section{KEYWORDS}

Works by Jiří Mahen, the book Měsíc, the book analysis and its reception, Ludvík Kundera, beginnings of existentialism in Czech literature.

\section{KLÍčovÁ SLOVA}

Tvorba Jiřího Mahena, kniha Měsíc, analýza této knihy a její recepce, Ludvík Kundera, počátky existencialismu v české literatuře.

Roku 1997 vyšla v brněnském nakladatelství Jota v celkově třetím vydání Mahenova knížka Měsíc v jednom svazku se souborem mahenovských studií literárního kritika a historika Milana Suchomela Jiné oči Jiřího Mahena. ${ }^{1}$ Když se Měsíc v roce 1920 objevil na knižním trhu, ${ }^{2}$ vzbudil značný zájem kritiků

1) Jiří Mahen: Měsíc (Fantazie), Milan Suchomel: Jiné oči Jiřího Mahena (Mahenưv Měsíc: text, kontext, čtenáři), grafická úprava Boris Mysliveček (přebal s použitím koláže Maxe Ernsta a obálka s použitím kresby Jaroslava Krále). Brno: JOTA, edice Odkaz sv. 7, 1997. Moje stat́ vznikla přepracováním a rozšířením recenze Mahenův Měsíc a jeho interpret v časopisu TVAR, r. 8, 1997, č. 21, s. 20-21. Tato recenze je také v mé knize Nesoustavná rukovět české literatury (Praha: Torst, 2003, s. 539-542).

2) Jiří Mahen: Měsíc (Fantazie), Praha: Stanislav Minařík, edice Knihy Země sv. 14, 1920. 
i čtenářŭ, ale druhé vydání vyšlo až dlouho po Mahenově smrti v roce 1968 v Odeonu. ${ }^{3}$ Suchomelovu souboru, druhé části této „dvojknihy“, dala název jedna z třiceti krátkých povídek a pohádek Mahenova Měsice Jiné oči.

Suchomelovy studie vznikly vznikaly v letech 1982-1995 a byly z větší části už publikovány ve Sborníku prací brněnské filozofické fakulty, v časopise Česká literatura aj., pro knižní vydání je autor upravil. Vydány v tomto celku tvoří významnou mahenovskou monografii; není to ovšem monografie v tradičním slova smyslu, zabývající se „svým“ autorem od kolébky až po citáty z nekrologů. Mahenovým životopisem se Suchomel nezabývá vůbec. Knížka Měsíc a její ohlas u čtenářů a kritiků mu otevřela širší problémy týkající se Mahena a recepce jeho tvorby a těmto problémům se postupně věnuje ve svých celkem sedmi vzájemně na sebe navazujících kapitolách.

Studie (stejně by se však hodil i termín eseje), napsané při vší vědecké přesnosti osobitým a vtipným jazykem, se zabývají nejen knihou Měsíc a Mahenem, ale i situací české literatury a kultury v prvním desítiletí samostatného státu a později. Pro svou analýzu volí Suchomel pokaždé jiný úhel pohledu, ale vždy je zároveň přítomen i pohled filozofa, jak k tomu vybízí tematická dominanta celé knížky, totiž Mahenův názor na polaritu omezených časových i prostorových možností pozemštanů na jedné straně a nekonečnosti vesmíru na straně druhé. Řečeno Suchomelovými slovy: „Světlo ve výši ční proti zemské temnotě, myslitelnými partnery lunárních božstev jsou božstva solární a podsvětní, dvojdobá směna noci a dne se prostupuje s rytmickou triádou zrození, smrti a nového života. [...] Vykladač, další v řadě, neměl na vybranou, nezbylo mu než vstoupit do té komunikační sítě a podstoupit riziko spoluúčasti, chtěl-li něčemu porozumět, měl-li nahlédnout, jak se proměňuje skutečnost v pohybu a utkvění slov“ (100-101).

Text Měsíce byl převzat z odeonského vydání, jehož editor Vlastimil Válek právem nepřijal úpravy, které ve svém díle provedl Mahen v roce 1930 při zařazení vybraných (celkem osmnácti) povídek z Měsice do knížky Člověk ve všech situacích, čtvrtého svazku svých Sebraných spisů v Družstevní práci, ${ }^{4}$ tehdejším Mahenově kmenovém nakladatelství. Mahen měnil především začátky příběhů a povídek. Tyto povídky totiž tvoří v Měsíci rámcový cyklus, vypráví je Měsíc

3) Jiři Mahen: Měsíc (Fantazie), k vydání připravil Vlastimil Válek, doslov napsal Ludvík Kundera, obálka, vazba, předsádky a frontispis Mikuláš Medek. Praha: Odeon 1968.

4) Jiří Mahen: Člověk ve všech situacích. Výbor próz, upravil a vyzdobil Eduard Milén. Praha: Družstevní práce, Sebrané spisy Jiřího Mahena, sv. 4, 1930. Mahenovy Sebrané spisy vydávané Družstevní prací, zůstaly torzem, stejně jako Dílo Jiř́ho Mahena, vydávané v padesátých letech minulého století za redakce Josefa Hrabáka nakladatelstvím Československý spisovatel v Praze. 
svému pozemskému partnerovi, který je svázán se svou rodnou planetou. Měsíc ze své dálky uvidí leccos, co se událo na Zemi v dávných dobách i současnosti, náměty jsou pestré a tematicky bohatě rozrůzněné - od antických mýtů a pohádkových motivů až po příhody ze světa zviřat a následky světové války. Povídky většinou začínají krátkým dialogem mezi vypravěčem Měsícem a jeho posluchačem. Tyto začátky Mahen pro vydání v Družstevní práci upravoval a měnil, přičemž mnohdy změnil i některá místa $\mathrm{v}$ textu a původní název próz (týká se to nejen Měsice, ale i knihy Díže aj.). Úpravy svědčí o tom, jak se měnil Mahenův přístup k vlastním textům, a pro poznání Mahena-spisovatele by proto mohlo být cenné obě verze podrobněji porovnat.

Když Měsíc v roce 1920 poprvé vyšel, ale jinak tomu nebylo ani později, soustředil se zájem a pozornost čtenářů hlavně na Mahenovu asi osmistránkovou předmluvu, adresovanou „Jeho Excelenci, panu markýzi d’Afterglow, velvyslanci Měsíční říše v Praze“. Fiktivním autorem zprávy je Algernon P. Moonshiner, sekční šéf v Ministerstvu osvěty, kterému markýz d’Afterglow poslal rukopis knihy Měsíc s žádostí o posudek. V posudku podává měsíční sekční šéf stručnou zprávu o vývoji české literatury a hlavně poezie - nejprve asi od roku 1400 na podkladě srovnání s velkými evropskými literaturami a od obrození zhruba do konce devatenáctého století pak podrobněji a už s pohledem na jednotlivé autory. Mahen při tom uživá metaforických názvi̊ zemí a jména českých i cizích autorů šifruje zkratkami nebo anagramy, někdy se o díle určitého autora zmíní, aniž uvede jeho jméno. Země Stínů je Německo, země Géniů Francie, země Barev Itálie, země Slunce a mlh Anglie, země Cizího zlata Španělsko. Česko je země Jediných Myšlenek, nebot', jak píše Milan Suchomel, „víc než jedinou myšlenku jako by český duch naráz neobsáhl či nepřipouštěl“ (105). „Ach, tento vichr Jediné Myšlenky, jakési Rozumovosti a stř́izlivosti čili tzv. jednoduchých linií! Dělá z básníků místo géniů ,svědomí národa' a básníci, kteři tušili problém poezie nad sebou, sedají na lep frázi, nad niž pro básníka nemůže být vražednější," soudí Mahen ve svém fingovaném dopisu měsíčního úředníka pražskému velvyslanci Měsíční říše (12-13).

Mahenova kniha je opět doplněna vtipným Doslovem, který napsal před padesáti lety, v roce 1968, pro vydání v Odeonu Ludvík Kundera. „Téměř po půlstoletí stál ještě Měsíc jinému básníkovi za to, aby ho znovu vydal a aby českou básnickou genealogii, kterou Mahen dovedl v předmluvě ke Karáskovi a Neumannovi, prodloužil [...] a aby v jiné situaci znovu svou edicí něco odmítal a něco obhajoval," konstatuje Suchomel v úvodu ke své knize (101). Kryt pseudonymem Patrick O’Newgerty, zastupující sekční šéf v Ministerstvu osvěty 
a kultury, navázal Kundera na Mahenovu předmluvu o charakteristických rysech české literatury od obrození a převzal od Mahena jak lehce humornou a diplomatický jazyk napodobující „měsíčni“" stylizaci textu, tak i to, že jména autorů a zemí jsou nahrazena iniciálami příjmení a metaforickými názvy. Dopis adresuje Jeho Excelenci panu markýzi d’Afterglow jun. Mahen v roce 1920 mluví o svém nástupci, který snad napíše definitivní memorandum o stavu české literatury, a Kundera si proto osobuje právo rozluštit Mahenovy zkratky, šifry a metafory. Ty nové, ze svého Doslovu, který začíná Mahenem, Josefem Čapkem, Demlem a Weinerem a pokračuje přes Wolkra, Horu, Nezvala, Biebla, Seiferta a Halase až k Holanovi, Hrubínovi a Mikuláškovi, však nedešifruje a nechává jejich rozluštění na čtenáři. Do výčtu zemí doplňuje Rusko, Zemi Východního slunce.

Právě Mahenově proslulé předmluvě je věnována první ze sedmi Suchomelových studií nazvaná Předmluva a její čtenáři, zvláště někteří. Suchomel konstatuje, že předmluva přitáhla více zájmu než povídky tvořící vlastní jádro knihy. Dobová kritika tehdy vyčítala Mahenovým příběhům a pohádkám, že jsou nevyrovnané kvality, „vyrozumované“, „bez tepla“ a „bez lásky“ aj., ale Suchomel se $k$ těmto kritikům nepřipojuje.

Hlavní výtka, kterou Mahen ústy úředníka Měsíčné říše adresuje české literatuře, je to, že u nás téměř nikdo neví, co je skutečná literatura, naše literatura do roku 1789 je „literaturou vlastně jen moralizující, poučnou, náboženskou a od roku 1650 skoro by se mohlo říci literaturou mrtvou“ (8). Ústředním problémem české literatury je podle Mahenovy předmluvy požadavek nebo potřeba, aby rozumářství a utilitární služebnost „jediné myšlence“ byly vystř́íány imaginací a čistou fantazií. Mahen zdaleka nepíše o všech autorech negativně, ale o „problému“, tj. o tom, jak má vypadat skutečná poezie, která není jen hlasatelkou náboženských, vlasteneckých nebo jiných idejí, vědí z jím uvedených autorů vlastně jenom Mácha, Neruda a Březina.

V roce 1920, kdy Mahen ve své předmluvě zdůrazňuje význam ničím neomezované fantazie, začíná u nás pod vlivem nedávno skončivší světové války a ruské revoluce nabývat vlivu směr, kterému ř́íáme proletářská poezie - Neumann, Hora, Hořejší, Seifert, o něco později Wolker atd. Je to opět literatura s tendencí, řečeno Mahenovými slovy, „vichr Jediné Myšlenky“ (12). Touto věcí se však Suchomel nezabývá, protože je mimo oblast jeho zájmu. Ostatně ani Mahen se $\mathrm{v}$ předmluvě ani jinde $\mathrm{v}$ Měsíci o proletářské poezii nezmiňuje.

Pro své zamyšlení nad Mahenovou předmluvou zvolil Milan Suchomel jako východisko rozbor referátů, které na počátku dvacátých let o Mahenově knížce 
napsali Jindřich Vodák, Arne Novák a Miloslav Novotný. Výsledkem je zdařilá a názorná charakteristika střetu dvou hodnotových světů - Mahenova buřičství a revolty a světa jeho kritiků, hájících v podstatě tradiční postoje. Jsou to světy protikladné, ale v určitých bodech se také stýkají a vzájemně doplňují a korigují. Vcelku však, jak Milan Suchomel dokládá, byli tito kritikové napojeni na jiné kódy než Mahen a nepochopili osobitost Mahenova př́stupu k látce a tématu.

Druhá studie Dědic Máchův?je věnována už zmíněnému vztahu mezi tvorbou Jiř́ho Mahena a odkazem Karla Hynka Máchy. Využívaje Lotmanova schématu romantismu, osvětluje Milan Suchomel z nového úhlu Mahenovy romantické kořeny a jeho chápání nihilismu. V tom, co Mahen napsal o Máchovi, „nepochybně poznáváme autoportrét Mahenův," píše Suchomel (119). Dodejme, že obdoby lze najít i v povaze obou autorů - u obou se $\mathrm{k}$ vášnivé citovosti druží vyhraněná racionalita, originální a přesné myšlení.

Suchomel se tu také ještě jednou vrací k Vodákovi a Arne Novákovi a všímá si jejich názorů na Máchu, jež zčásti korespondují s tím, jak hodnotili Mahenův Měsíc. Zároveň autor charakterizuje shody a rozdíly mezi Mahenovou předmluvou k Měsíci a názory Šaldovými, jak je zformuloval zejména v přednášce Moderní literatura česká z roku 1909. ${ }^{5}$ Šaldova slavná přednáška klade před spisovatele vlastně obdobné požadavky jako Mahen. Šalda také neměl rád epigonství, falešný idylismus a díla, z nichž trčí vlastenecká nebo jiná tendence. Zároveň však, jak uvádí Milan Suchomel, „přitakává klasicismu a jeho touze po zákonnosti, po krásném hutném tvaru“ (117). Suchomel také stručně rekapituluje Šaldovy názory na Mahena a jeho básnické a dramatické dílo od prvotiny Plamínky přes villonské Balady a odmítavou kritiku Jánošíka až po krásný a smířlivý dopis v jubilejním sborníku z roku $1932 .{ }^{6}$ O Měsíci Šalda nikde nepsal.

Ve třetí a čtvrté studii Nezval, čtenář Mahena a Spor spřízněných sleduje Suchomel ohlas četby Měsíce u Nezvala a Halase a spolu i vztah obou básníků k Mahenovi a celku jeho díla. Oba mladí básníci měli Měsíc rádi a hlásili se k němu, ale s rozdílnými akcenty. Nezval podtrhuje zvláště Mahenovo zdưraznění čisté

5) F. X. Šalda: Moderní literatura česká. In: Studie z české literatury, Soubor díla F. X. Šaldy, sv. 8. (Praha: Československý spisovatel), ed. Rudolf Havel, 1961, s. 9-59.

6) F. X. Šalda: Pozdrav Jiřímu Mahenovi. In: Mahenovi. Sborník k padesátinám, uspoř. František Halas a Jiří Žantovský, s. 61-63. (Praha: Družstevní práce) 1933. Ke vztahu Šalda-Mahen připomínám Mahenovu brožuru O umění Boženy Němcové a Růženy Svobodové (Brno: Stanislav Kočí), Nápady a výpady, sv. 2, 1921, kterou Mahen vydal pod pseudonymem Červená maska. Mahen v ní kritizuje precióznost a afektovanost prozaického stylu Šaldovy (již zesnulé) přítelkyně a srovnává citace z jejího díla s prostým a přirozeným jazykem Boženy Němcové. Šalda mu krátce odpověděl v článku O díle Růženy Svobodové, v němž reagoval i na jiné názory o spisovatelčině díle (Kritika 1, 1924, in: Kritické projevy 12, 1922-1924, Soubor díla F. X. Šaldy, sv. 2, ed. Z. Trochová /Praha: Československý spisovatel 1959/, s. 304-306). Suchomel se o Mahenově brožuře nezmiňuje, připojuji tuto poznámku jen jako zajímavou a málo známou podrobnost. 
fantazie a odmítání didaktičnosti a vidí v tom argument pro svůj vlastní básnický vývoj od prvotiny Most přes Podivuhodného kouzelníka k poetismu. Halas si všímá hlavně metafyzické stránky Měsíce, u Mahena podle něho číhá prrízrak nicoty, z jeho díla vybuchuje úzkost a Mahen statečně zápasí o její překonání. „My o těch černých řekách víme víc než jiní," psal Halas Mahenovi v říjnu 1936. ${ }^{7}$ Halasovo pojetí poezie a přístupu k tvorbě je bližší autentickému Mahenovi, pro něhož posledním cílem nebyl volný rozlet fantazie, ale řešení záhady lidské existence a boj o skutečnou lidskost. Suchomel poukazuje na to, že Nezval ve dvacátých a třicátých letech vylučoval z poezie ideologické otázky a jakékoli „vysvětlování“ názorů, ale v reálném socialismu se „Nezvalovo opojení bezbranně podřídilo ideologickému tlaku, neschopné odolávat mu“ (150). To samozřejmě není nic překvapivého, ale Suchomel podrobně analyzuje vlastnosti a postoje obou básníků zrcadlící se v jejich tvorbě, zjištěné pojmy a vztahy sestavuje do dvou proti sobě (nebo vedle sebe) stojících sloupců a ukazuje, kdo byl bližší Mahenovi - a v tom je objevnost a novost jeho analýz.

Suchomelem konstatovaný rozdíl má paralelu i v biografických faktech. Zatímco přátelství s Halasem trvalo ničím nenarušeno až do Mahenovy smrti, ve vztahu Mahen - Nezval došlo v posledních letech Mahenova života z iniciativy autora Měsíce dokonce $\mathrm{k}$ úplnému přerušení přátelských styků. Hlavním, ale ne jediným důvodem roztržky s Nezvalem bylo to, že Nezval se Mahenovi nepřiznal $\mathrm{k}$ autorství knihy, $\mathrm{v}$ níž kráčel ve stopách svého staršího přítele, totiž anonymně vydané sbírky Padesát dva hořkých balad věčného studenta Roberta Davida (1936). Mahen vydal sbírku villonských balad už roku 1908, a proto se v diskusích o tom, kdo stojí za verši Roberta Davida, objevovalo i jméno Mahenovo. Za autora básní „věčného studenta“ byli považováni také Otokar Fischer, Josef Mach, Eduard Bass a jiní, dokonce i za světové války zmizelý František Gellner. Nejvíc se však objevoval správný tip, totiž že knihu napsal „podivuhodný kouzelník“ Vítězslav Nezval. Mahen se 4. prosince 1936 obrátil na Nezvala s dotazem, zda je opravdu autorem knížky Padesát dva hořkých balad. Předpokládal, že kdyby se za Davidem skrýval Nezval, určitě by se svému učiteli a vřele milovanému příteli přiznal. Nezval mu však 11. prosince odpověděl vyhýbavě: „Ty balady, o nichž píšeš, jsou, mimo jiné, přisuzovány i Tobě. Doufám, že jsi už docela zdráv a že je všecko v nejlepším pořádku." ${ }^{\text {"To }}$ To Mena rozzlobilo. Když jej pak Nezval po čase přišel navštívit a paní Karla mu šla otevřít, otevřel Mahen dveře pracovny v prvním patře „[...] a volal tak, aby to Nezval dole slyšel: Řekni,

7) Halas: Dopisy, Dílo Františka Halase, sv. 6, eds. Jan Halas a Ludvík Kundera (Praha: Torst) 2001, s. 126.

8) Adresát Jiří Mahen. Připravili a komentáře napsali Jiří Hek a Štěpán Vlašín (Praha: SNKLU) 1964, s. 75. 
že nejsem doma.“ „Bylo to pro mne těžké,“ píše Karla Mahenová, „ale Nezval pochopil a odešel. “9 Nové (alespoň pro mne) bylo Suchomelovo zjištění, že když Nezval psal o Mahenovi, často používal výroků z Mahenových dopisů, aniž přiznal, že jde o citáty.

Ve studii Nepravý Dionýsos přináší Milan Suchomel detailní naratologickou analýzu prózy Láska, patnácté prózy z Mahenovy třicítky. Je to parabola o tom, jak vášnivá láska vede někdy ke smrti obou - milujícího i milovaného. V knize Člověk ve všech situacích dal Mahen povídce název Kentaur a Dryáda. Suchomel ji rozložil na 19 dějových motivů a podrobně sleduje děj až k tragickému konci. Analyzuje přitom nejen její kompozici, ale i syntax a lexikum. Ve výčtu dějových motivů úmyslně neuvedl hrozivé zmínky o černém pardálu. Černý pardál „vstupuje do příběhu pětkrát, a to pravidelně, vždy na konci odstavce, vždy jedinou větou a vždy ve stejné úpravě grafické, totiž uzavřen do závorek. [...] Svým umístěním plní funkci motivické kadence či motivického rýmu," píše Suchomel (166). Stojí za zmínku, že ve výboru z Družstevní práce Mahen tyto závorky vynechal, ale na funkci motivu pardála se nic nezměnilo, proto to Suchomel pomíjí. Studii o povídce Láska doplňuje rozbor dionýského mýtu a jeho transformace v průběhu staletí - od řeckých tragédií až po Nietzscheho a naše současníky.

V posledních dvou statích Systém, ale bláznivý a Jiné oči se Suchomel věnuje mj. kompozičnímu uspořádání celého Mahenova souboru. To podle Suchomela není náhodné, je v něm určitý záměr. Suchomel dokládá, že celou knížku provází antitetičnost. Při zmínce o jednotlivých prózách autor zároveň upozorňuje na symbolické významy některých motivů, kterých si čtenáři při běžném čtení zpravidla nevšimnou - je to např. bizarní poloha člověka v Měsícově vyprávění Věčná tragikomedie. „Dole - nahoře je základní opozice všech textů Měsíce, je hlavní osou napětí, podél níž se prostor textu rozkládá a naplňuje. [...] Nahoře je Měsíc, dole je člověk a dole se stále něčeho nedostává. Člověk je jenom člověk, $v$ tom je jeho nedostatečnost, ale je na cestě $\mathrm{k}$ překonání své nedostatečnosti, protože touží po něčem víc, než je sám“ (180-181). „Člověk touží nad sebe a v důsledku toho se rozchází se sebou, překračuje, co je mu dáno. Ztrácí tím svou jistotu, své zakotvení, ale získává svou podstatu, která je právě v tom neřešitelném rozporu. Nepatří docela ani Zemi, ani nebesům, ale patři sobě. Není nadzemštanem, nadčlověkem, není bohem, není ani prostým pozemským živočichem. Je bytostí, která dospěla k ironickému sebepochopení. Je to existenciální situace, která by se dala vyslovit také existencialistickým oxymórem:

9) Karla Mahenová: Život s Jiřím Mahenem. Předmluva Štěpán Vlašín, text vybrali a uspořádali Štěpán Vlašín a Jan Veselý (Praha: Mladá fronta) 1978, s. 138. 
člověk je tím, čím není, je svým vlastním projektem, je vždy znovu esenciálně tím, k čemu svou existencí nedosáhl... (184-185).

Suchomel poměřuje Mahenovu knihu - úvodní dialogy, syžety jednotlivých próz i jejich vyústění - nejrůznějšími myšlenkovými koncepcemi moderní doby a dochází k závažnému zjištění, že Měsíc je už předzvěstí existencialismu v české literatuře, takže „prvopočátky českého existencialismu jsou časnější, než se soudilo, a tkvějí v domácí půdě, nebyly odkázány na cizozemský import“ (185).

Suchomelova kniha se nečte lehce, při četbě je třeba se vracet $\mathrm{k}$ textu Měsice a k autorovým předchozím zmínkám o jednotlivých prózách nebo jiných Mahenových dílech, ale odměnou je nový vhled do Mahenova světa. Charakterizovat Suchomelovu metodu v práci s literárním dílem není snadné. Suchomel jako by rýsoval kolem Mahenova Měsíce větší a větší soustředné kružnice, vraceje se při tom stále $\mathrm{k}$ svému východisku - Mahenovu textu a jeho recepci. Souvislosti a paralely hledá $\mathrm{v}$ celém Mahenově díle, ale zároveň i v názorech myslitelů devatenáctého a dvacátého století od Nietzscheho a Bergsona k Heideggerovi, Frommovi, Derridovi, Eliadovi, Foucaultovi a dalším. Měsíc se v této filozofické intepretaci ocitá někde poblíž Slavné Nemesis Ladislava Klímy jako kniha, jež je předzvěstí postmoderního pocitu krize ustálených hodnot, kdy končí „věk rozumu“ a víra v lineární pokrok. Mahenův hrdina s tímto postojem bojuje, vrací se pro posilu až k mýtům a dávným snům lidstva, ale „zůstává trvale v mezipásmu mezi svým rozmachem a svou nezpůsobilostí dosáhnout cíle, dojít do konce. Jeho síla se nerozpoutá do tragické velikosti [...], protože rek sám od začátku ví, že chce nemožné“ (196).

\section{PramenY}

MAHEN, Jiří

1920 Měsic (Fantazie) (Praha: Stanislav Minařík), edice Knihy Země sv. 14

1921 O uměni Růženy Němcové a Boženy Svobodové (Brno: Stanislav Kočí), Nápady a výpady, sv. 2 1930 Člověk ve všech situacích (Praha: Družstevní práce), Sebrané spisy Jiřího Mahena, sv. 4 1968 Měsíc (Fantazie). Vlastimil Válek (ed.) (Praha: Odeon)

\section{LITERATURA}

ADRESÁt JiŘí MAHEN

1964 Jiří Hek a Štěpán Vlašín (eds.) (Praha: SNKLU) 
HALAS, František

2001 Jan Halas a Ludvík Kundera (eds.) Dopisy. Dílo Františka Halase, sv. 6 (Praha: Torst 2001)

MAHENOVÁ, Karla

1978 Život s Jiřim Mahenem. Štěpán Vlašín a Jan Veselý (eds.) (Praha: Mladá fronta)

RAMBOUSEK, Jiř́

2003 Nesoustavná rukovět české literatury (Praha: Torst)

SUCHOMEL, Milan

1997 Jiné oči Jiřího Mahena (Brno: JOTA), edice Odkaz, sv. 7

ŠALDA, František X.

1933 František Halas a Jiří Žantovský (eds.) „Pozdrav Jiřímu Mahenovi“, in Mahenovi. Sborník kpadesátinám (Praha: Družstevní práce), s. 61-63

1959 „O díle Růženy Svobodové“ (Kritika 1, 1924, in: Kritické projevy 12, 1922-1924, Soubor díla F. X. Šaldy, sv. 2, Zina Trochová (ed.) (Praha: Československý spisovatel), s. 304-306

1961 Rudolf Havel (ed.) „Moderní literatura česká“, in Studie z české literatury, Soubor díla F. X. Šaldy, sv. 8 (Praha: Československý spisovatel), s. 9-59

Doc. PhDr. Jiří Rambousek, CSc., jiriram@seznam.cz, Brno, Česká republika / Brno, Czech Republic 